
Kartu Huruf bagi Siswa Kelas I SD Negeri 023898 Kota Binjai T.A. 2016/2017. MUKADIMAH, 1(2), 188-197.

\title{
Upaya Meningkatkan Belajar Membaca Permulaan melalui Alat Peraga Gambar dan Kartu Huruf bagi Siswa Kelas I SD Negeri 023898 Kota Binjai T.A. 2016/2017
}

\author{
Masriani \\ Guru SD Negeri 023898 Kota Binjai
}

\begin{abstract}
ABSTRAK
Sebagai upaya tindak lanjut pemberdayaan kualitas belajar mengajar, tulisan ini mempelajari berbagai metode mengajar yang tepat untuk pembelajaran berikutnya. Salah satu metode yang sering digunakan dalam pembelajaran Bahasa Indonesia adalah metode Gambar. Metode ini menyajikan bagaimana melatih siswa bekerja dengan timnya secara aktif. Rumusan masalah dalam penelitian ini adalah penggunaan metode Gambar yang dapat meningkatkan hasil belajar siswa dalam belajar Bahasa Indonesia di kelas I SD Negeri 023898 Binjai Timur. Dari hasil kegiatan pembelajaran yang telah dilakukan selama dua siklus, dan berdasarkan seluruh pembahasan serta analisis yang telah dilakukan dapat disimpulkan sebagai berikut: Pembelajaran dengan berbasis Gambar memiliki dampak positif dalam meningkatkan hasil belajar siswa yang ditandai dengan peningkatan ketuntasan belajar siswa dalam setiap siklus, yaitu siklus I (50\%), siklus II (100\%). Penerapan metode Gambar mempunyai pengaruh positif, yaitu dapat meningkatkan hasil dan motivasi belajar siswa yang ditunjukan dengan hasil tes siklus siswa, rata-rata jawaban siswa menunjukkan bahwa siswa berhasil dalam pembelajaran dengan menggunakan metode Gambar sehingga mereka menjadi termotivasi untuk belajar sehingga hasil belajar dapat dicapai.
\end{abstract}

Kata kunci: Hasil belajar, gambar, Bahasa Indonesia.

\section{PENDAHULUAN}

Manusia sebagai salah satu makhuk ciptaan Tuhan yang mempunyai keunggulan bila dibandingkan dengan makhluk-makhluk lainnya. Karena manusia dibekali dengan akal budi dan kemampuan untuk berfikir, berkomunikasi dengan sesamanya. Bahasa menjadi sarana komunikasi utama. Tanpa bahasa manusia tidak dapat berkomunikasi dengan sesamanya.

Program pendidikan untuk siswa sama dengan jenis program yang diperuntukkan bagi jenjang-jenjang pendidikan untuk anak-anak. Demikian juga dalam kegiatan belajar mengajar siswa juga harus disesuaikan dengan tingkat kecerdasannya. Salah satu hal yang perlu diperhatikan dalam 
penyelenggaraan kegiatan belajar mengajar bagi siswa dengan menggunakan metode yang digunakan untuk menyampaikan materi pelajaran. Pemilihan metode mengajar yang tepat tentu akan menjadikan proses belajar mengajar akan terasa hidup, artinya siswa akan aktif dalam menerima pelajaran yang disampaikan guru. Dengan adanya siswa yang aktif merespons pelajaran, berarti dalam proses belajar mengajar terjadi adanya interaksi timbal balik antara siswa dengan guru. Interaksi belajar mengajar di sekolah merupakan interaksi yang berencana secara umum, yang menjadi rencana pengajaran adalah kurikulum. Sedangkan secara khusus, rencana pengajaran adalah Garis Besar Program Pengajaran (GBPP).

Menurut Dirjen Pendidikan Dasar dan Menengah Depdikbud, pengantar belajar mengajar atau proses pembelajaran merupakan bagian yang tidak dapat dipisahkan dari proses pendidikan, karena pembelajaran merupakan bagian dari pendidikan. Dalam strategi pembelajaran dapat disamakan dengan metode atau teknik penyampaian mata pelajaran kepada siswa, agar tujuan belajar mengajar dapat tercapai.

Berdasarkan pengalaman guru di SD, banyak siswa mengalami hambatan dan kesulitan dalam membaca, terutama membaca permulaan. Untuk itu guru harus bisa memberikan alat peraga yang cocok atau sesuai untuk anak didik, agar anak didik ada minat dalam belajar terutama dalam hal membaca permulaan.

Permasalahan yang berhubungan dengan rendahnya minat belajar membaca permulaan adalah: selama ini guru lebih banyak menggunakan metode ceramah, setiap siswa mempunyai cara belajar yang berbeda, dan guru mengajar dengan cara klasikal belum tentu cocok dengan pola belajar siswa, sebagian hasil belajar siswa rendah dalam membaca permulaan.

Agar pelaksanaan pengajaran Bahasa Indonesia di Sekolah Dasar dapat berjalan lancar dan dapat mencapai tujuan, diperlukan perencanaan yang matang, termasuk minat belajar dalam belajar membaca permulaan dengan menggunakan alat peraga Gambar dan Kartu Huruf.

Untuk meningkatkan hasil belajar siswa kelas I SD Negeri 023898 Binjai pada pelajaran Bahasa Indonesia yang berkaitan dengan minat belajar membaca permulaan melalui pembelajaran yang menerapkan alat peraga Gambar dan Kartu Huruf, maka melalui Penelitian Tindakan Kelas (PTK) peneliti memperbaiki sistem pembelajaran agar siswa dapat:

1) Aktif;

2) Tertarik pada materi yang disampaikan oleh guru dalam proses pembelajaran;

3) Termotivasi;

4) Lebih cepat dan mudah menguasai materi.

Berdasarkan latar belakang masalah tersebut di atas dapat diungkapkan identifikasi masalah: metode pembelajaran yang konvensional dan kurang 
bervariasi; kurangnya (rendahnya) minat dan motivasi belajar siswa; kurangnya penggunaan alat peraga dalam kegiatan pembelajaran; rendahnya tingkat kecerdasan siswa; rendahnya dorongan belajar dari orang tua.

Agar penelitian ini mempunyai arah yang jelas dan mudah dilaksanakan, maka permasalahan perlu dibatasi, yakni dalam penelitian ini yang menjadi subyek penelitian adalah Siswa Kelas I SD Negeri 023898 Binjai tahun pelajaran 2016/2017 dan yang menjadi obyek penelitian dalam penelitian ini adalah alat peraga Gambar dan Kartu Huruf dalam membaca permulaan.

Berdasarkan latar belakang dan pembatasan masalah seperti yang telah diuraikan di depan, maka dapat dirumuskan permasalahan sebagai berikut: "Apakah Penggunaan alat peraga Gambar dan Kartu Huruf dalam Pembelajaran dapat meningkatkan minat belajar membaca permulaan pada Siswa Kelas I SD Negeri 023898 Binjai tahun pelajaran 2016/2017?"

Adapun tujuan dari penelitian ini adalah untuk meningkatkan minat belajar membaca permulaan melalui pembelajaran yang menerapkan alat peraga Gambar dan Kartu Huruf bagi Siswa Kelas I SD Negeri 023898 Binjai tahun pelajaran 2016/2017.

Hasil penelitian diharapkan dapat bermanfaat untuk mendapatkan pengetahuan melalui pembelajaran yang menetapkan alat peraga Gambar dan Kartu Huruf untuk meningkatkan minat belajar membaca permulaan. Manfaat bagi siswa adalah dengan alat peraga Gambar dan Kartu Huruf, siswa dapat meningkatkan minat belajar membaca permulaan. Manfaat bagi guru adalah dengan penelitian ini guru dapat mengetahui minat belajar permulaan dengan alat peraga Gambar dan Kartu Huruf. Manfaat bagi sekolah adalah sekolah mempunyai alat peraga yang lengkap dan menarik untuk pembelajaran membaca permulaan.

\section{METODE DAN PENDEKATAN}

Metode dan Pendekatan dalam penelitian ini adalah Penelitian Tindakan Kelas (PTK) dalam bahasa Inggris diartikan Classroom Action Research (CAR) yaitu penelitian yang dilakukan oleh guru di kelas atau di sekolah tempat mengajar, dengan penekanan pada penyempurnaan atau peningkatan praktek dan proses dalam pembelajaran. Penelitian dilaksanakan di Kelas I SD Negeri 023898 Binjai pada pembelajaran bahasa Indonesia pada Semester I tahun pelajaran 2016/2017.

\section{HASIL DAN PEMBAHASAN}

Menurut Usman Moh. Uzer (Uzer, 2002, p. 27) minat besar sekali pengaruhnya terhadap belajar sebab dengan minat seseorang akan melakukan sesuatu yang diminatinya. Sedangkan menurut Mohibbin Syah (Syah, 2005, p. 151) Secara sederhana minat diartikan kecenderungan dan kegairahan yang tinggi atau keinginan yang besar terhadap sesuatu. Minat yang ada pada diri seseorang 
bergantung pada berbagai faktor internal yang lain seperti pemusatan perhatian, keingintahuan,motivasi dan kebutuhan.

Agar seseorang menjadi termotivasi, ada dua faktor yang mempengaruhi yaitu faktor intrinsik dan faktor ekstrinsik. Motivasi intrinsik atau yang tumbuh dari diri siswa sendiri memiliki kedudukan yang lebih penting dalam pembelajaran karena sifatnya yang relatif langgeng. Termasuk kategori ini perasaan menyenangi materi dan kebutuhannya terhadap materi tersebut, termasuk di dalamnya, jika seseorang merasakan ada manfaatnya untuk dilakukan, melihat pentingnya minat dalam mencapai tujuan anda (Porter, Reardon, \& Nourie, 2002, p. 51).

Motivasi yang besar pada diri seseorang akan mendorongnya belajar lebih efektif dan cepat. Ini bukan berarti bahwa minat yang terlalu besar adalah baik, berbagai hasil penelitian menunjukkan hasil tersebut. Pembelajaran seorang guru seyogyanya mampu membangkitkan minat siswa untuk menguasai pengetahuan yang terkandung dalam bidang studinya. Minat menurut Kamus Besar Bahasa Indonesia adalah kecenderungan hati yang tinggi terhadap suatu gairah keinginan.

Menurut Gagne, belajar adalah merupakan perubahan yang diperlihatkan dalam bentuk tingkah laku yang keadaannya berbeda dari sebelum individu berada dalam situasi belajar dan sesudah melakukan tindakan yang sempurna itu. Menurut para ahli psikologi, belajar merupakan suatu proses perubahan, yaitu perubahan tingkah laku sebagai hasil dari interaksi dengan lingkungannya dalam memenuhi kebutuhan hidup. Belajar adalah suatu aktifitas mental atau psikis ysng berlangsung dalam interaksi aktif dengan lingkungan, yang menghasilkan perubahan-perubahan dalam pengetahuan, pemahaman, keterampilan dan nilai sikap, perubahan itu relatif dan berbekas.

Sumadi Suryabrata (Suryabrata, 1983, p. 25) mengemukakan bahwa untuk mendapatkan gambaran tentang belajar ada beberapa hal pokok dalam belajar adalah bahwa belajar itu membawa perubahan, bahwa perubahan itu pada pokoknya adalah didapatkannya kecakapan yang baru dan bahwa perubahan itu terjadi karena usaha dengan sengaja.

Berdasarkan pendapat-pendapat tersebut di atas, maka ditarik pengertian bahwa belajar adalah proses kegiatan atau aktivitas yang dilakukan oleh individu secara sadar yang mengakibatkan perubahan dalam diri individu berkat pengalaman dan latihan. Berhasil atau tidak seseorang dalam belajar disebabkan beberapa faktor-faktor yang mempengaruhi pencapaian hasil belajar.

Faktor-faktor yang mempengaruhi banyak jenisnya, tetapi digolongkan menjadi dua golongan yaitu faktor intern dan faktor ekstern. Faktor intern adalah faktor yang ada dalam individu seperti: faktor kesehatan, bakat, perhatian. Sedangkan faktor ekstern adalah faktor yang ada di luar individu 
(dirinya) seperti: keluarga, sekolah, dan masyarakat. Faktor-faktor yang mempengaruhi minat belajar tersebut antara lain faktor biologis dan faktor kesehatan.

Kesehatan jasmani dan rohani sangat besar pengaruhnya terhadap kemampuan belajar, bila seseorang kesehatannya terganggu dapat mengakibatkan cepat lelah, tidak bergairah dan tidak bersemangat untuk belajar. Demikian halnya jika kesehatan rohani seseorang kurang baik, misalnya mengalami perasaan kecewa karena putus cinta atau sebab lainnya, ini bisa mengganggu ataupun mengurangi semangat belajar, oleh karena itu pemeliharaan kesehatan sangat penting bagi setiap orang baik fisik maupun mental, agar badan tetap kuat pikiran selalu segar dan semangat dalam melaksanakan kegiatan belajar. Sebab lainnya, ini bisa mengganggu ataupun mengurangi semangat belajar, oleh karena itu pemeliharaan kesehatan sangat penting bagi setiap orang baik fisik maupun mental, agar badan tetap kuat pikiran selalu segar dan semangat dalam melaksanakan kegiatan belajar.

Untuk mencapai hasil belajar yang baik, maka siswa harus mempunyai perhatian terhadap bahan yang dipelajarinya jika bahan atau materi pelajaran tidak menjadi perhatian siswa, maka minat belajar pun rendah, jika begitu akan timbul kebosanan, siswa tidak bergairah belajar, siswa tidak lagi suka belajar. Agar siswa berminat dalam belajar usahakanlah bahan atau materi pelajaran selalu menarik perhatian, salah satunya usaha tersebut adalah dengan menggunakan variasi gaya mengajar yang sesuai dan tepat dengan materi pelajaran.

Kesiapan adalah kesediaan untuk memberikan respon atau bereaksi, kesediaan itu timbul dalan diri seseorang dan juga berhubungan dengan kematangan, karena kematangan berarti kesiapan untuk melaksanakan kecakapan. Jika tarif pertumbuhan pribadi telah memungkinkannya, potensipotensi jasmani atau rohani telah matang untuk menerima karena jika siswa atau anak yang belajar itu sudah ada kesiapan, maka hasil belajarnya akan lebih baik daripada anak yang belum ada kesiapan.

Bakat adalah kemampuan untuk belajar, kemampuan itu baru akan terealisasi menjadi kecakapan yang nyata sesudah belajar. Bakat bisa mempengaruhi belajar jika bahan pelajaran yang dipelajari siswa sesuai dengan bakat, maka siswa akan berminat terhadap pelajaran tersebut, jadi kedua aspek kejiwaan ini besar sekali pengaruhnya terhadap minat belajar dan keberhasilan belajar.

Mengembangkan minat terhadap suatu benda pada dasarnya adalah membantu siswa melihat bagaimana melihat pengetahuan atau kecakapan tertentu mempengaruhi dirinya, jika siswa sudah sadar bahwa belajar merupakan alat untuk mencapai beberapa tujuan yang dianggap penting, maka belajarnya akan membawa kemajuan pada dirinya dan otomatis dia bersemangat dalam mempelajari hal tersebut. Pada kenyataannya tidak semua siswa sadar akan hal itu, dan tidak semua siswa memiliki minat intrinsik yang 
sama, dengan ketidaksamaan minat tersebut guru hendaknya mengetahui seberapa besar minat tersebut terhadap pelajaran.

Beberapa ahli pendidikan berpendapat bahwa cara yang paling efektif untuk membangkitkan minat pada suatu subyek yang baru adalah dengan menggunakan minat-minat siswa yang telah ada. Membaca permulaan merupakan tahapan proses belajar membaca bagi siswa kelas awal, siswa belajar untuk memperoleh kemampuan dan menguasai teknik-teknik membaca, oleh karena itu guru perlu merancang pembelajaran membaca dengan baik sehingga mampu menumbuhkan kebiasaan membaca sebagai sesuatu yang menyenangkan. Proses pembelajaran membaca yaitu dengan cara membaca per huruf, per suku kata dan kata.

Pada tingkatan membaca permulaan pembaca belum memiliki keterampilan membaca yang sesungguhnya, tetapi masih dalam tahap belajar untuk memperoleh keterampilan atau kemampuan membaca. Membaca permulaan ini merupakan kegiatan belajar mengenal bahasa tulis. Melalui tulisan itulah siswa dituntut dapat menyuarakan lambang-lambang bunyi bahasa tersebut, untuk memperolaeh kemampuan membaca diperlukan tiga syarat yaitu; kemampuan membunyikan lambang-lambang tulis,penguasaan kosa kata untuk memberi arti dan memasukkan makna dalam kemahiran bahasa.

Menurut Moh Amin (Amin, 1995, pp. 207-209) istilah membaca permulaan biasanya digunakan pada pelajaran membaca siswa ringan. Membaca permulaan merupakan suatu proses keterampilan dan kognitif, proses keterampilan menunjuk pada pengenalan dan penguasaan lambanglambang fonem sedangkan proses kognitif menunjuk pada penggunaan lambang-lambang fonem yang sudah dikenal untuk memahami makna suatu kata atau kalimat.

Pembelajaran membaca permulaan diberikan dikelas I dan II, tujuannya adalah agar siswa memiliki kemampuan memahami dan menyuarakan tulisan dengan intonasi yang wajar, sebagai dasar untuk membaca lanjut. Pembelajaran membaca permulaan merupakan tingkatan prases pembelajaran membaca untuk menguasai sistem tulisan sebagai representasi visual bahasa, tingkatan ini sering disebut dengan tingkatan belajar membaca. Untuk mengajar membaca permulaan, telah dikenal adanya berbagai metode yang bisa digunakan, yaitu metode suara, metode abjad, metode suku kata, metode kata lembaga, metode frase, metode kalimat dan metode cerita.

Pertama-tama siswa diperkenalkan bahwa kata-kata yang digunakan sehari-hari itu tersusun dari suara atau bunyi vokal dan konsonan yang berturut-turut. Setelah siswa mencoba membunyikan suara-suara itu satu per satu kepadanya diperkenalkan satu atau dua huruf yang menggambarkan suara tersebut. Metode ini diperbolehkan mulai diperkenalkan abjad dari huruf yang mana saja bukan menerangkan huruf-huruf A sampai dengan $\mathrm{Z}$ secara berturut-turut, huruf diperkenalkan satu demi satu bunyinya 
diperkenalkan seperti dalam abjad. Metode ini mulai dengan mengajarkan suku-suku kata kemudian suku kata digabungkan menjadi kata dan diuraikan menjadi huruf.

Berbeda dengan metode abjad dan metode suara, dalam metode ini murid tidak langsung berkenalan dengan huruf, melainkan diperkenalkan satu atau dua kata yang mengandung unsur yang sama, biasanya satu suku kata atau dua suku kata. Yang dimaksud dengan frase adalah rentetan atau gugus kata yang mempunya arti tetapi tidak merupakan kalimat dan sebutan. Dalam metode kalimat yang mula-mula diajarkan adalah kalimat dan tulisannya mula-mula diperkenalkan dua atau tiga kalimat yang mempunyai kata-kata yang sama. Dalam metode cerita guru dan murid membuat cerita bersamasama cerita tersebut dikristalisasikan menjadi beberapa kalimat yang disusun bersam-sama oleh guru dan murid, murid membaca kalimat-kalimat dengan kata-kata seperti halnya dalam metode kalimat.

Adapun fungsi alat peraga adalah untuk membangkitkan motivasi atau kegairahan dalam belajar, memberikan kejelasan, memberikan rangsangan mempersemakan pengalaman, memungkinkan belajar sendiri-sendiri menurut kemampuan dan minat anak. Tujuan digunakannya alat peraga adalah memberikan kemampuan berpikir secara kreatif, mengembangkan suasana dalam pembelajaran yang dapat membuat siswa memperoleh kepercayaan diri akan kemampuannya dalam belajar, memberikan motivasi dan memudahkan, dengan alat peraga siswa dapat belajar dengan memperoleh pengalaman yang baru dan menyenangkan. Dari tujuan di atas diharapkan dengan bantuan penggunaan alat peraga dalam pembelajaran lebih menarik bagi siswa-siswa yang sedang melakukan kegiatan belajar oleh karena itu sebaiknya setiap alat peraga dilengkapi dengan kartu-kartu atau lembar kerja.

Gambar sebagai salah satu pembelajaran guru dalam mengatur proses pengajarannya serta menggunakan waktu di kelas dengan bijak. Media pembelajaran dalam pelajaran Bahasa Indonesia khususnya membaca permulaan menggunakan alat peraga Gambar dan Kartu Huruf, agar siswa ada minat belajar terutama membaca permulaan dengan menggunakan alat peraga Gambar dan Kartu Huruf. Dengan media Gambar dan Kartu Huruf tersebut akan mendukung siswa dalam pencapaian pembelajaran itu sendiri.

Di antara media pembelajaran, media Gambar dan Kartu Huruf adalah media yang paling umum dipakai, karena siswa lebih menyukai gambar daripada tulisan, apalagi jika Gambar dan Kartu Huruf dibuat dan disajikan dengan baik dan menarik, sudah tentu akan menambah semangat siswa dalam mengikuti proses pembelajaran, sehingga siswa ada minat untuk belajar terutama membaca dengan media Gambar dan Kartu Huruf.

Minat sangat besar pengaruhnya terhadap belajar, karena minat siswa merupakan faktor utama yang menentukan derajat keaktifan siswa, bila bahan pelajaran yang dipelajari tidak sesuai dengan minat siswa, siswa tidak akan belajar dengan baik, sebab tidak ada daya tarik baginya, oleh karena itu untuk 
mengatasi siswa yang kurang berminat dalam belajar, terutama dalam membaca permulaan, guru hendaknya berusaha bagaimana menciptakan kondisi tertentu agar siswa ada minat dan selalu terus belajar, siswa mempunyai minat belajar yang besar, mungkin dengan cara menjelaskan halhal yang menarik, salah satunya mengembangkan variasi dalam gaya mengajar, agar siswa merasa senang dan memperoleh kepuasan terhadap belajar terutama dalam membaca permulaan terhadap alat peraga Gambar dan Kartu Huruf siswa betul-betul berminat dalam pelajaran tersebut. Minat sangat erat hubungannya dengan belajar, belajar tanpa minat akan terasa jemu, dalam kenyataannya tidak semua belajar siswa didorong oleh faktor minatnya sendiri, ada yang mengembangkan minatnya terhadap materi pelajaran dikarenakan pengaruh dari gurunya, temannya, orang tuanya, oleh sebab itu sudah menjadi kewajiban dan tanggung jawab sekolah untuk menyediakan situasi dan kondisi yang bisa merangsang minat siswa terhadap belajar, dalam hal ini pengaruh alat peraga terhadap minat belajar membaca permulaan.

\section{Hasil Penelitian}

SD Negeri 023898 Binjai adalah suatu sekolah yang dikelola untuk pendidikan. Proses pembelajarannya anak SD Kelas I lebih menekankan pada keterampilan mandiri yaitu untuk memberikan bekal keterampilan pada anak agar kelak di masyarakat bisa hidup mandiri seperti anak pada umumnya.

Dengan pembelajaran yang menekankan pada bidang keterampilan inilah mata pelajaran yang lain bukan bidang keterampilan kurang mendapat perlakuan yang serius dari para guru. Dalam Proses Belajar Mengajar guru belum mengoptimalkan metode, teknik, pendekatan, media dan alat pembelajaran. Hal ini sangat berpengaruh terhadap minat, motivasi dan prestasi siswa. Dengan kondisi di lapangan yang seperti di atas peneliti mencoba untuk secara khusus mengadakan penelitian terhadap minat siswa dalam belajar Bahasa Indonesia pada membaca permulaan untuk Siswa Kelas I SD Negeri 023898 Binjai.

Siswa Kelas I SD Negeri 023898 Binjai terdiri dari 24 anak dengan latar belakang sosial, kecerdasan, keaktifan, minat belajar, daya konsentrasi yang berbeda, berikut data anak Kelas I SD Negeri 023898 Binjai. Dalam mengikuti pelajaran rata-rata kurang berminat, daya konsentrasi anak rata-rata rendah dan rata-rata status ekonomi orang tuanya 2 (dua) dari ekonomi kurang mampu dan 2 (dua) cukup. Dengan kondisi latar belakang anak seperti itu diperlukan perhatian secara khusus dalam proses pembelajarannya, untuk itu diperlukan suatu metode, pendekatan dan alat peraga yang bisa diterima oleh semua anak tentunya dengan perhatian, bimbingan secara khusus untuk masing-masing anak sesuai dengan kebutuhan anak, hal ini memerlukan kecermatan guru dalam pelaksanaan proses belajar mengajar.

Sebelum penelitian ini dilaksanakan, pembelajaran Bahasa Indonesia pada aspek membaca permulaan masih dilaksanakan dengan metode konvensional yaitu guru melafalkan, huruf, suku kata, membaca kata, siswa 
menirukan, kemudian siswa diberi waktu untuk latihan membaca dan secara bergilir diperintah untuk membaca. Dengan metode ini banyak siswa yang takut dan tidak mau bila disuruh membaca apalagi maju untuk membaca di depan kelas.

\section{PENUTUP}

Berdasarkan hasil Penelitian Tindakan Kelas yang telah dilaksanakan dalam 2 (dua) siklus dengan menggunakan alat peraga gambar dan kartu huruf dalam pembelajaran siswa kelas I SD Negeri 023898 Binjai dapat dibuat simpulan bahwa "Pembelajaran Bahasa Indonesia tentang membaca permulaan dengan alat peraga Gambar dan Kartu Huruf dapat meningkatkan minat anak dalam pembelajaran". Berdasarkan hasil Penelitian Tindakan Kelas dengan menggunakan 2 (dua) siklus tersebut di atas, ternyata hipotesis yang dirumuskan telah terbukti akan kebenarannya, bahwa pembelajaran Bahasa Indonesia dengan menerapkan alat peraga Gambar dan Kartu Huruf dapat meningkatkan minat belajar membaca permulaan bagi siswa Kelas I SD Negeri 023898 Binjai Tahun 2016/2017.

Pada pra Silkus nilai terendah 55 pada Siklus I meningkat nilai terendah menjadi 70 dan pada Siklus II menjadi 80. Perolehan nilai tertinggi meningkat pada pra Siklus nilai tertinggi 65 pada Siklus I meningkat menjadi 75 dan pada Siklus II menjadi 90, walaupun siswa yang memperoleh nilai tertinggi tersebut sama. Kenaikan juga terlihat pada perolehan nilai rata-rata, pada pra siklus nilai rata-rata 58,91 pada Siklus I naik menjadi 72,17 dan pada Siklus II naik menjadi 85,65 demikian juga pencapaian ketuntasan belajar juga meningkat pada pra Siklus 0\% pada Siklus I meningkat. Menjadi $75 \%$ dan pada Siklus II dapat mencapai $100 \%$.

Pembelajaran membaca permulaan dengan alat peraga Gambar dan Kartu Huruf diperlukan dalam pembelajaran Bahasa Indonesia pada tahap membaca permulaan, karena alat peraga Gambar dapat lebih bermakna. Bagi Siswa diharapkan dalam mengikuti pembelajaran khususnya mata pelajaran bahasa Indonesia dapat lebih aktif dan kreatif. Bagi guru hendaknya dalam pembelajaran lebih kreatif dalam menerapkan alat peraga, untuk meningkatkan minat belajar siswa.

\section{REFERENSI}

Abdurrahman, M. (1999). Pendidikan Anak Berkesulitan Belajar. Jakarta: Rineka Cipta.

Abdurrahman, M., \& S, S. (1994). Pendidikan Luar Biasa Umum. Direktorat Jenderal Pendidikan Tinggi Proyek Pendidikan Tenaga Akademik Depdikbud.

Amin, M. (1995). Ortopedagogik Anak Berkelainan. Jakarta: Bumi Aksara.

Arikunto, S. (2006). Penelitian Tindakan Kelas. Jakarta: Bumi Aksara. 
Dasiemi, E. (1995). Psikiatri. Surakarta: FKIP UNS.

Delphie, B. (2006). Pembelajaran Anak Berkebutuhan Khusus. Bandung: Refika Aditama.

Depdiknas. (2006). Kurikulum KTSP SK dan KD Mata Pelajaran Bahasa Indonesia. Jakarta: BSNP.

Munzayanah. (1998). Tuna Grahita. Surakarta: PLB FKIP UNS.

Nasution, S. (2000). Berbagai Pendekatan dalam Proses Belajar Mengajar. Jakarta: Bumi Aksara.

Porter, B. de, Reardon, M., \& Nourie, S. S. (2002). Quantum Teaching: Mempraktikan Quantum Learning di Ruang-ruang Kelas. Bandung: Kaifa.

Somantri, S. (1996). Psikologi Anak Luar Biasa. Jakarta: Depdikbud.

Suryabrata, S. (1983). Pembimbing Psycodiagnostik I. Yogyakarta: Fakultas Psikologi UGM.

Syah, M. (2005). Psikologi Belajar. Jakarta: Rajawali Press.

Uzer, U. M. (2002). Menjadi Guru Profesional. Bandung: Remaja Rosdakarya. 